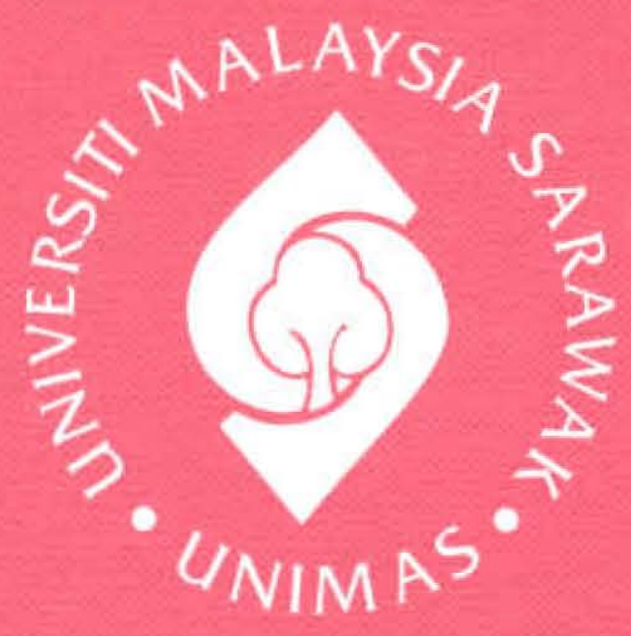

Faculty of Engineering

\title{
SLOPE STABILITY ANALYSIS
}

ONG CHEE ZEN 
UNIVERSITI MALAYSIA SARAWAK

BORANG PENYERAHAN STATUS TESIS

Judul: SLOPE STABILITY ANALYSIS

Sesi Pengajian: $2004-2005$

Saya ONG CHEE ZEN

(HURUF BESAR)

mengaku membenarkan tesis * ini disimpan di Pusat Khidmat Makiumat Akademik, Universiti Malaysia Sarawak dengan syarat-syarat kegunaan seperti bcrikut:

I. Tesis adalah hamilik Universiti Malaysia Sarawak.

2. Pusat Khidmat Maklumat Akademik, Universiti Malaysia Sarawak dibenarkan membuat salinan untuk tujuan pengajian sahaja.

3. Membuat pengdigitan untuk membangunkan Pengkalan Data Kandungan Tempatan.

4. Pusat Khidmat maklumat Akademik, Universiti Malaysia Sarawak dibenarkan membuat salinan tesis ini sebagai bahan pertukaran antara institusi pengajian tinggi.

5. ** Sila tandakan ( $\sqrt{ }$ ) di kotak berkenaan

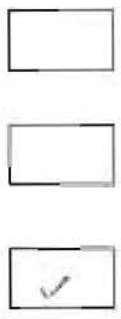

SULIT

(Mengandungi inaklumat yang berdariah keselamatan atau kepentingan Malaysia seperti yang termaktub di dalam AKTA RAHSIA RASMI 1972)

TERHAD

(Menganclungi maklumat TERHAD yang telah ditentukan oleh organisasi/badan di mana penyelidikan dijalankan).

TIDAK TERHAD

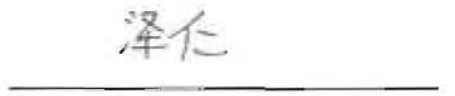

(TANDATANGAN PENULIS)

ALAMAT TETAP:

17. Taman Srimewah.

Jalan Cnderawasih.

05460, Alor Selar.

Kedah.

Tarikh:

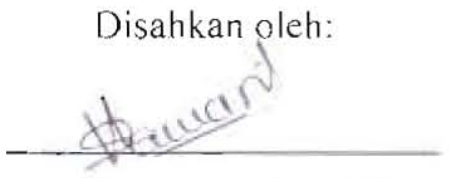

(TANDATANGAN PENYELIA)

Dr. Vishwas A. Sawant

Nama Penyelia

Tarikh:

CATATAN * Tests dimaksudkan sebagai lesis bagi Ija Łah Doktor Falsafah, Sarjana dan Sarjana Muda

** Jiha tesis ini SULL. Th atau TERHAD, sila lampirkan surat daripada pihak berkuassiorganisasi berken aran dengan meny atakan sekalı sebab daa tempuh tesis ini perlu dikelaskan sebagai SI LIT dan TERHAD. 
The following Final Year Project Report:

Title : SLOPE STABILITY ANALYSIS

Name

: ONG CHEE ZEN

Matrix Number : 7479

has been read and approved by :

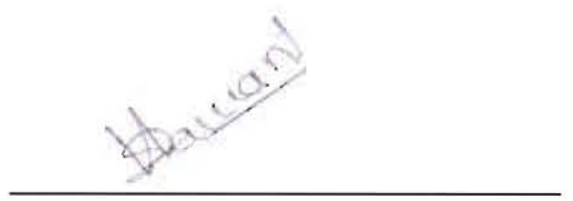

DR. VISHWAS SAWANT

Date

Project Supervisor 


\section{SLOPE STBILITY ANALYSIS}

\section{ONG CHEE ZEN}

This project is submitted in partial of fulfilment of the requirements for the degree of Bachelor of Engineering with Honours (Civil Engineering) 


\section{ACKNOWLEDGEMENT}

First of all, I would like to render my sincere thanks to my supervisor, Dr.

Vishwas Sawant for his valuable guidance. His experience in the subject has drawn up to this synopsis to an extent which cannot be cxpressed by more words. His sincere help at every stage of this parametric synopsis has seen us through this good piece of work

I also want to thank my beloved father and mother for all their moral and financial supports within this year, and also to my dearest brothers and sisters for all of their help and supports. Last but not least, thank you to all my friends who have shared their suggestions and evaluations of this script. 


\section{ABSTRACT}

Slope is an exposed ground surface that stands at an angle with the horizontal.

If the component of gravity is large enough, which mean driving force overcomes the shear strength of the soil along the rupture surface, slope failure can occur. There are few method developed for checking the safety of slopes. Among them the Morgenstern and Price method has been chosen for this parametric study. Morgenstren and Price Method is used for analyzing the slope stability in moment equilibrium for general slip slope surface. Normal and shear forces acting on vertical sides of the slice are also taken into account. Proportionality, constant, $\lambda$, between shear and normal force, is treated as unknown along with the factor of safety, F. The values of these two unknowns, ( $\mathrm{F}$ and $\lambda$ ) are evaluated using an iterative procedure. $\mathrm{A}$ software program is written in Fortran90, which calculates the minimum factor of safety for a certain slope angle and height, with a soil parameters. From the present parametric study, with a constant slope angle, factor of safety increases with angle of internal friction and cohesion. Next, for a given friction angle, factor of safety decreases with slope angle. Beside, for a given cohesion, factor of safety decreases with slope angle. 


\section{ABSTRAK}

Cerun merupakan permukaan ysng berada dalam keadaan bersudut dengan garis mengufuk. Jika daya tarikan graviti yang cukup, ini bermaksud daya tarikan sudah mengatasi shear strength tanah pada permukaan gelangsar, kagagalan cerun akan berlaku.Terdapat beberapa kaedah analisis telah diperkenalkan bagi tujuan penentuan kestabilan cerun. Antaranya kaedah Morgenstern and Price telah dipilih untuk kajian parametric. Kaedah Morgenstern and Price digunakan untuk analisis kestabilan momen bagi permukaan cerun. Daya ricih dan normal bertindak ke atas arah menegak bagi cerun. Kadar pemalar $\lambda$, dengan daya ricih dan daya normal dianggap sebagai anu-anu bagi factor keselamatan, F. Nilai $\mathrm{F}$ dan $\lambda$ daanalisis dengan kaedah iterative. Satu perisian dituliskan dalam FROTRAN90 untuk penggiraan minimum factor keselamatan dengan sudat kecerunan dan ketinggian cerun, serta parameter tanah tertentu. Bagi kajian parametric ini, diberi kecerunan sudut sebagai permalar, factor keselamatan meningkat dengan sudut tanah dan cohesion meningkat. K.emudian, diberi sudut tanah sebagai permalar, factor keselamatan menurun dengan sudut cerun meningkat. Selain itu, diberi cohesion sebagai permalar, factor keselamatan menurun dengan sudut cerun meningkat. 


\section{TABLE OF CONTENTS}

ACKNOWLEDGEMENT

ABSTRACT

ABSTRAK

TABLE OF CONTENTS

iv

LIST OF TABLES

vii

LIST OF FIGURES viii

LIST OF NOMENLATURES

ix

CHAPTER 1

INTRODUCTION

1.1 GENERAL

1.2 HISTORICAL BACKGROUND 2

1.3 TYPE OF SLOPE 3

1.3.1 NATURAL 3

1.3.2 EXCAVATED SLOPES 4

1.3.3 SLOPES OF EMBANKMENTS AND EARTH DAMS 4

1.4 PROJECT OBJECTIVE 5 
CHAPTER 2 LITERATURE REVIEW

2.1 INTRODUCTION 6

2.2 FELLENIUS METHOD ANALYSIS 7

2.3 SWEDISH CIRCLE SLICES METHOD 9

2.4 BISHOP'S SIMPLIFIED METHOD OF ANALYSIS OF 12 FINITE SLOPE

2.5 JANBU METHOD (NON-CIRCULAR FAILURE SURFACE)

CHAPTER 3 METHOLOGY

$\begin{array}{lll}3.1 & \text { GENERAL } & 17\end{array}$

3.2 MORGENSTERN AND PRICE METHOD

CHAPTER 4 RESULTS AND DISCUSSION

4.I PARAMETER AND PROPERTIES 23

CHAPTER 5 CONCLUSION 
APPENDIXA DERIVATIVE FOR MORGENSTERN

AND PRICE METHOD

APPENDIX B FORTRAN PROGRAM ON ANALYSIS OF

SLOPE AND STABILITY

APPENDIXC RESULTS FOR FROTRAN PROGRAM 


\section{LIST OF TABLES}

TABLE

PAGE

Table 2.I Factor of safety which related to detail of slope 7

Table 4.1 Result for FORTRAN Programming 24 


\section{LIST OF FIGURES}

FIGURE

PAGE

Figure 2.I Fellenius method of slope stability analysis 8

Figure 2.2 Stability analysis by Swedish circle method 9

Figure 2.3 Bishop's simplified method; forces acting on the slice 12

$\begin{array}{lll}\text { Figure 2.4 Limited graph for the method Janbu } & 15\end{array}$

$\begin{array}{lll}\text { Figure 3.1 The forces acting on single slice } & 18\end{array}$

Figure 4.1 Factor Of Safety vs Angle of internal friction $\varphi$ at 25

Slope Angle $40^{\circ}$

Figure 4.2 Lamda, $\lambda$ vs Angle of internal friction, $\varphi$ at Slope angle $40^{\circ} \quad 25$

Figure 4.3 Factor of Safety vs Slope Angle which Angle of friction $\varphi$ is $30^{\circ} \quad 27$

Figure 4.4 Lamda, $\lambda$ vs Slope Angle which Angle of friction $\varphi$ is $30^{\circ} \quad 27$

Figure 4.5 Factor of Safety. F vs Slope Angle which Cohesion Cu is $30 \quad 28$

Figure 4.6 Lamda, $\lambda$ vs Slope Angle which Cohesion $\mathrm{Cu}$ is $30 \quad 28$ 


\section{LIST OF NOMENLATURES}

$\begin{array}{ll}F & \text { Factor of Safety } \\ \lambda & \text { Lamda } \\ \phi & \text { Angle of internal friction } \\ C_{u} & \text { Cohesion } \\ X_{c} & \text { Horizontal distance measured from centroid of circle } \\ Y_{c} & \text { Vertical distance measured from centroid of circle } \\ H & \text { Height of slope } \\ \beta & \text { Slope angle } \\ W & \text { Weight of small slices } \\ \gamma & \text { Density of soil }\end{array}$




\section{CHAPTER 1}

\section{INTRODUCTION}

\subsection{GENARAL}

An exposed ground surface that stands at an angle with the horizontal is called an unrestrained slope. The slope can be natural or man made. If the ground surface is not horizontal, a component of gravity will tend to move the soil downward. If the component of gravity is large enough, slope failure can occur. The driving force overcomes the resistance from the shear strength of the soil along the rupture surface. Slope failures can cause enormous damage to property and loss of human lives.

In many cases, civil engineers are expected to make calculations to check the safety of natural slopes, slopes of excavation, and compacted embankments. This check involves determining and comparing the shear stress developed along the most likely rupture surface with the shear strength of the soil. This process is called slope 
stability analysis. The most likely rupture surface is the critical plane that has the minimum factor of safety.

The stability analysis of a slope is not an easy task. Evaluation of variables such as the soil stratification and its in-place shear strength parameters by prove to be formidable task. Seepage through the slope and the choice of a potential slip surface add to complexity of the problem.

\subsection{HISTORICAL BACKGROUND}

The development of limit equilibrium methods based on the plastic equilibrium of trial failure surface began in Sweden in 1916, following the failure of a number of quay walls at Gothenburg Harbor. Petterson (1955) and Hultin (1916) in separate publications reported that the failure surfaces in the soft clays of Gothengurg Harbor closely resembled arcs of eircles. Over the next few years the friction circle method of analysis was devised, results from simple undrained shear tests were used with reasonable success in predicting stability ( $S_{\mathrm{u}}$ or $\varphi=0$ analysis), and the method of slices was introduced (Fellenius, 1927). The concept of pore water pressure and the effective stress method of analysis were introduced by Terzaghi (1967). Improved soil strength measurements resulted from better sampling techniques, the development of the triaxial shear test, and the measurement of pore pressures. Improved methods of analysis that include the side forces between slices were developed, beginning with Fellenius (1936) and Bishop (1955). More rigorous 
analytical methods usually involving the use of digital computer are available. However, despite the use of more rigorous methods of analysis and improved soiltesting techniques, may uncertainties remain in predicting the stability of slope. These uncertainties are primarily associated with the measurement of soil strength (Johnson, 1975) and the prediction of pore pressures

\subsection{TYPE OF SLOPE}

\subsubsection{NATURAL}

The routes by which a natural (not man-made) slope has reached its present state may be split into two main categories:-

1 Those which are made up of a series of long-term processes, many of which are still active,

2 Those which are made up of processes which act for a short duration, so much fewer active processes carry on at present.

This second category of slope takes much more investigation to discern the original cause of slope formation, and an understanding of these processes is essential for a successful engineering investigation, and to know how to deal with problems of instability which may arise. 


\subsubsection{EXCAVATED SLOPES}

It is critical to pay attention to the pore water pressures as they tend to increase over time. This means that cheap, undrained shear strength tests are only use ful if looking at very short term stability.

The geological sequence and history must be known so we are sure if there are existing tectonic shears. Excavations are more susceptible to the effects of tectonic shears than embankments because embankments raise the normal effective stresses on potential sliding surfaces, and these offset the increased levels of shear stress they impose.

\subsubsection{SLOPES OF EMBANKMENTS AND EARTH DAMS}

Embankments are constructed by placing and compacting successive layers of a fill material onto a foundation soil. Construction causes the total stress in the embankment layers themselves, and also in the foundation soil, to increase. The initial pore water pressure $\left(u_{0}\right)$ depends primarily on the placement water content of the fill.

At the end of construction of an embankment, the Factor of Safety is lower than in the long term. This is because water dissipates after the end of construction, with the pore water pressure decreasing to the final, long term value. This assumes the permeability of the compacted fill layers is low, so not much dissipation takes 
place during construction. The construction period is usually quite short. Stability may also depend on the shear strength of the foundation soil.

\subsection{PROJECT OBJECTIVE}

The main objective of the project is to study the merits and demerits of available classical methods of slope stability analysis and select a more rational method which considers the parameter like pore pressure and horizontal pressure. A parametric study is aimed to find out the effect of soil parameters and slope parameters. 


\section{CHAPTER 2}

\section{LITERATURE REVIEW}

\subsection{INTRODUCTION}

Over the past decade, the slope stability analysis had been examined extensively, using numerical methods, particularly integral equation or boundary element method. Such methods developed out with formulas to show how the slope is affected by the parameter of the characteristic of soil. All solution is simplified by the factor of safety .Next, the pore water pressure of soil had been considered. By considering pore water pressure of soil at the potential sliding slope, the simplified formulas for factor of safety had been generated. 
Table 2.1: Factor of safety which related to detail of slope

\begin{tabular}{|c|c|}
\hline FACTOR OF SAFETY & DETAILS OF SLOPE \\
\hline$<1.0$ & Unsafe \\
\hline $1.0-1.25$ & Questionable safety \\
\hline $1.25-1.4$ & $\begin{array}{l}\text { Satisfactory for routine cuts and fills, Questionable for } \\
\text { dams, or where failure would be catastrophic }\end{array}$ \\
\hline$>1.4$ & Satisfactory for dams \\
\hline
\end{tabular}

In this chapter, following methods are reviewed:

1. Fellenius method of analysis

2. Swedish circle slices method

3. Bishop's simplified method of analysis of Finite slope

4. Janbu method

\subsection{FELLENIUS METHOD OF ANALYSIS}

Referring to Figure 2.1 , the total weight $W$ of the soil above the failure surface that cause the instability in slope. The weight $\mathrm{W}$ is given by the area between below the slope and until the failure surface of radius $R$. The moment of the driving force, $M_{\delta}$, about the center of circle to cause slope instability is given as follows.

$M_{d}=W \cdot x$ 


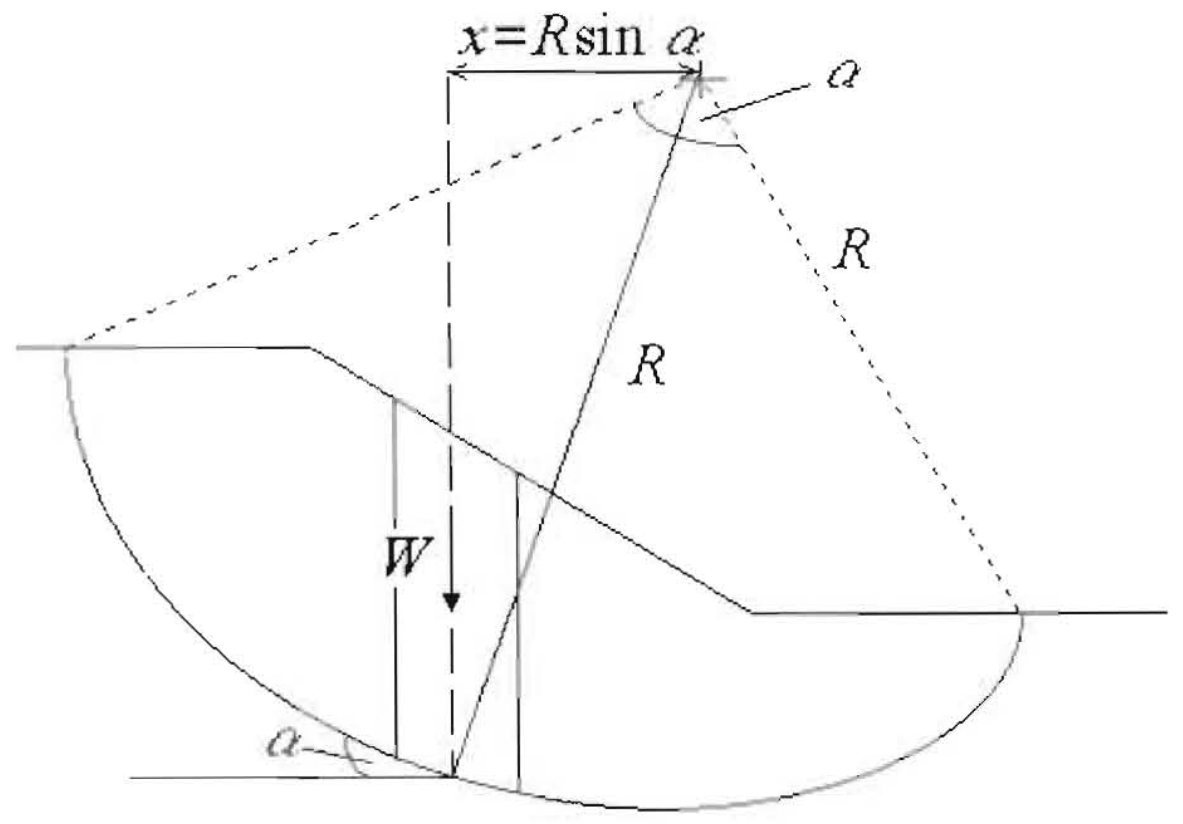

Figure 2.1: Fellenius method of slope stability analysis

In which, $\mathrm{x}$ is horizontal distance between centre of the circle and the centre of gravity of weight, $\mathrm{W}$.

The resistance to sliding is derived from the cohesion mobilized along the potential surface of sliding. If $\mathrm{c}_{\mathrm{m}}$ is the mobilized cohesion, then the resisting moment, $\mathrm{M}_{\mathrm{r}}$, is given by

$$
M_{r}=c_{m} L \cdot R=c_{m} R^{2} \alpha
$$

$\alpha$ is the angle subtended by the assumed failure arc, of length $\mathrm{L}$.

For equilibrium, $M_{r}=M_{d}$ Hence,

$$
\begin{gathered}
W x=c_{m} R^{2} \alpha \\
c_{m i}=\frac{W x}{R^{2} \alpha}
\end{gathered}
$$


The factor of safety against sliding, FS is given by the ratio of shear strength of soil, $\tau_{f}$ ( Undrained shear strength $\mathrm{c}$ in this case) to the mobilized shear strength, $\tau_{\mathrm{m}}$.

$$
F S=\frac{\tau_{1}}{\tau_{m}}=\frac{c}{c_{m}}=\frac{c R^{2} \alpha}{W x}
$$

\subsection{SWEDISH CIRCLE SLICES METHOD}

Swidish Circle Slices Method is a general method that can be used for both cohesive and $c-\varphi$ soils. The soil above the trial failure surface is divided into several vertical slices. Usually 6 to 12 slices are recommended. The width of each slices need not be the same. But a new slice should be considered at the interface of the changed soil layer.

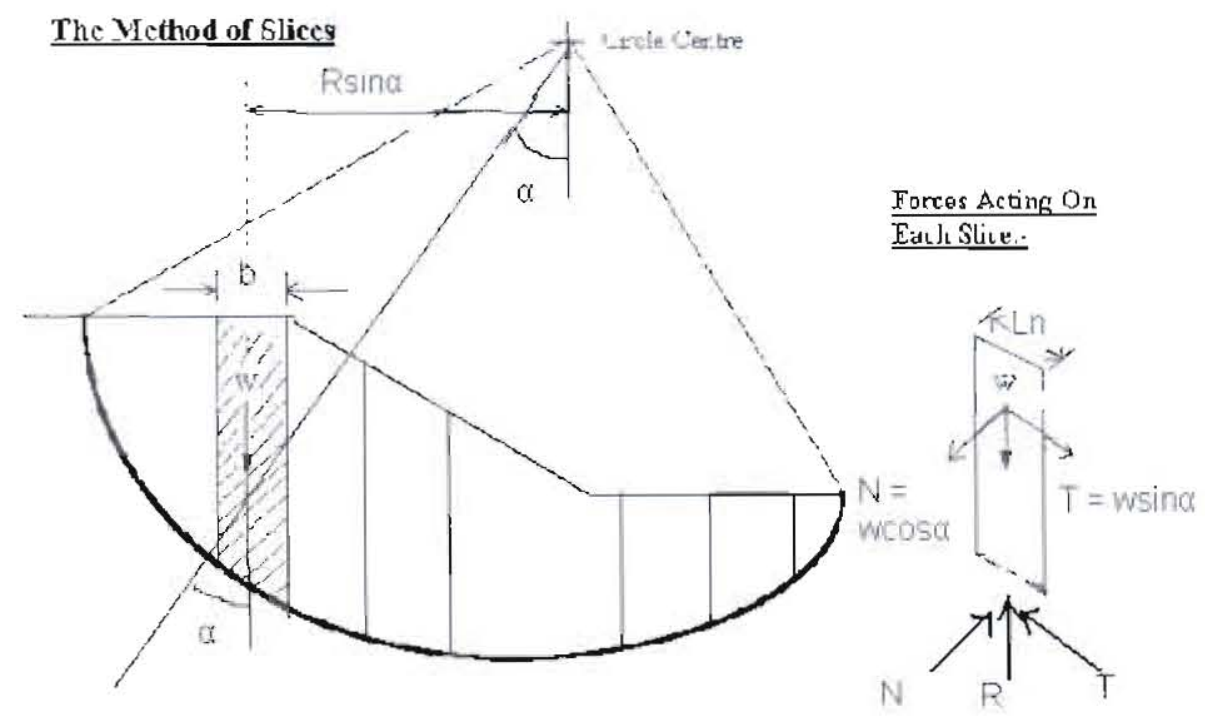

Figure 2.2: Stability analysis by Swedish circle method 
Figure 2.2 shows the forces that act on a typical slice for unit perpendicular length.

Let $\mathrm{W}$ be the weight of the slice. The forces $\mathrm{N}$ and $\mathrm{T}$ are the normal and tangential components of the reaction $R$, respectively. $P_{n}$ and $P_{n+1}$ are the normal forces that act on the sides of the slice. For simplicity, the pore water pressure is assumes to be zero. It is also assumed that both the normal and tangential forces on the sides of the slices are equal in magnitude and their line of action coincides. As such these forces will be cancelled out and not shown in the figure.

For equilibrium consideration

$$
\mathrm{N}=\mathrm{W} \cos \alpha
$$

The resisting shear force can be expressed as

$$
T=\tau_{m} L_{n}=\frac{\tau_{,} L_{n}}{F S}=\frac{(c+\sigma \tan \phi) L_{n}}{F S}
$$

Now, normal stress $\sigma=\frac{N}{L_{n}}=\frac{W \cos \alpha}{L_{n}}$

For equilibrium of the trial wedge, the moment of the driving force about $O$ equals the moment of the resisting force about that point. Therefore,

$$
\begin{aligned}
& \sum W \sin \alpha \cdot r=\sum\left(\frac{c+\left(\frac{W \cos \alpha \cdot \tan \varphi}{L_{n}}\right)}{F S}\right) \cdot L_{n} r \\
& \sum W \sin \alpha \cdot r=\sum\left(\frac{c L_{n}+W \cos \alpha \tan \varphi}{F S}\right) \cdot r
\end{aligned}
$$




$$
F S=\frac{\sum c L_{n}+W \cos \alpha \tan \varphi}{\sum W \sin \alpha}
$$

Note that $\mathrm{L}_{\mathrm{n}}$ is approximately equal to $\frac{B_{n}}{\cos \alpha} \cdot \mathrm{B}_{\mathrm{n}}$ is the width of the $\mathrm{n}^{\text {th }}$ slice.

\section{$\underline{\text { Steady state seepage }}$}

For steady state seepage through slopes, as is the situation in many practical cases, the pore water pressure must be considered when effective stress parameters are used.

For the nth slices, the average pore water pressure at the bottom of the slice is equal to $u=h \cdot \gamma_{w}$. Total force caused by the pore water pressure at the bottom of $n$th slice is equal to $u \times L_{n}$. Thus the equation for factor of safety, would be modified as

$$
F S=\frac{\sum c L_{n}+\left(W \cos \alpha-u L_{n}\right) \tan \varphi}{\sum W \sin \alpha}
$$

